\title{
Carbon Dioxide Emissions Research and Sustainable Transportation in the Sports Industry
}

\author{
Stavros Triantafyllidis
}

The Citadel, The Military College of South Carolina, Charleston, SC 29409, USA; triandafylides@gmail.com or striantaf@citadel.edu; Tel.: +1-(843)-408-8625

Received: 26 September 2018; Accepted: 23 October 2018; Published: 25 October 2018

\begin{abstract}
The sports industry is an institution that has large responsibility toward global environmental pollution. Over the past decade sports organizations have initiated a variety of environmentally sustainable practices. In this paper, the role of research in $\mathrm{CO}_{2}$ emissions generated by the sports industry pursuits is highlighted. This report recommends that strategic management approaches and policy development are required to control this dangerous environmental pollutant. Specifically, proactive sustainable innovations and policies that mandate alternative transportation behaviors are suggested. In conclusion, after reviewing the current literature, it is proposed that sports associations should apply specific practices in sports events with focus on spectators' mobility choices such as sustainable transportation.
\end{abstract}

Keywords: carbon research; sustainable transportation; sports event; climate change

\section{Introduction}

Degradation of the natural environment and its resources has been highlighted by climate scientists because of the human activities that generate carbon dioxide $\left(\mathrm{CO}_{2}\right)$ emissions [1]. People who are involved with sports often engage in practices that produce large amounts of $\mathrm{CO}_{2}$ emissions [2]. Accordingly, the estimated quantity of $\mathrm{CO}_{2}$ emissions from sports practices such as transportation, the construction of sport facility and production of sporting goods and services is a significant threat to the quality of the natural environment [2,3]. The United Nations Environmental Program (UNEP) (2018) has turned its focus to sports activities related operations due to the negative impact of these activities on global ecosystems and the large quantity of $\mathrm{CO}_{2}$ emissions derived from sports-related operations [4]. Specifically, UNEP's (2018) latest commentary stated that sports events, sports facilities, transportation, and the manufacture and consumption of sporting goods have a significant negative impact on the natural environment [4]. Equivalently, United States Environmental Protection Agency (US EPA) (2018) has turned its focus on sport and the environment and developed an agenda with strategies and policies that aim to reduce the impact of sport expansion on environmental resources [5]. An objective of US EPA's agenda is to advocate environmental sustainability on the sports industry and motivate sports organizations and consumers to become pro-active in terms of the large carbon footprint production [5]. For example, by controlling sports facilities' functions, sports consumption and travel behaviors in sport, it could potentially mitigate the environmental pollution and limit the degradation of environmental habitats [6]. Essentially, an appropriate management of $\mathrm{CO}_{2}$ emissions in the sports industry would mean that a large portion of the cause of climate change could be controlled [5-7].

\section{Environmental Efforts}

Sport organizations are initiating environmental sustainability efforts in their everyday business operations [8]. For example, the International Olympic Committee (IOC) provides documentation 
with required environmental initiatives to countries and cities that bid to host the Olympic and Paralympic Games [9]. For instance, Agenda 2020 is a policy document that contains guidelines and procedures on how sports organizations that host the Olympic Games can reduce their impact on the natural environment [9]. In addition, environmental efforts constitute practices that aim to reduce $\mathrm{CO}_{2}$ emissions generated by any activity associated with them $[8,9]$. In an effort to be more environmentally sustainable, sports organizations are constantly looking for ways to reduce energy, water and paper consumption and promote practices that have an environmentally friendlier outcome, such as recycling, the construction of green buildings, and the use of sustainable modes of transport [10]. Research has found that corporate social responsibility as a strategic approach by a sports association has a significant effect on the organizational value [11,12]. Accordingly, if a sports organization has environmental values and promotes environmental initiatives, then its sports consumers seek to act in a more sustainable manner $[13,14]$.

\section{Carbon Dioxide Sources}

The activities of sports organizations that are related to $\mathrm{CO}_{2}$ emissions include the function of sports facilities, water and solid waste management plants, electricity and water consumption, transportation of sports teams, and the distribution of sport manufactured products and services [12,13]. The external-nature includes activities in which the sports consumer is engage, such as the consumption of sports products and services which results in the large generation of waste and traveling behavior such as single operation vehicle (SOV) usage [12-14]. Accordingly, an operation that requires the involvement of both the internal and external associate of a sports organization is the sporting event [13-15]. Evidence shows that a large quantity of $\mathrm{CO}_{2}$ emissions is generated during a sports event [12-16]. For instance, in to host a sporting event, large outdoor space is required where sports organizations could accommodate the sport teams, the employees, and the volunteers and facilitate its consumers [14-16]. Spectators have a bond with their favorite sports team and as consumers, they contribute to the highest quantity of $\mathrm{CO}_{2}$ emissions [4-16]. Specifically, the emotional connection between spectators and sports teams result in overconsumption habits related to sports products and services, attending sporting events, purchasing sports goods, and consuming food and beverages [14-17] In addition, the largest quantity of $\mathrm{CO}_{2}$ emissions is derived from spectators' transportation and travel to the place of the event $[18,19]$.

\section{Sporting Events}

The number of spectators traveling to attend a sporting event has increased dramatically over the past decade [2,3]. Evidence has shown that in Europe, 25.6 million spectators travel to attend large-scale sporting events $[20,21]$. With respect to the quantity of $\mathrm{CO}_{2}$ emissions, 25.6 million spectators generate 210,000 tons of $\mathrm{CO}_{2}$ emissions and $8 \mathrm{~kg}$ of $\mathrm{CO}_{2}$ is emitted by each individual [18-24]. Some other cases found that 15 million spectators traveled to the place of only one sporting event (e.g., the cycling event Tour de France) [22-24]. In Major League Baseball (MLB), 73 million people attend annual baseball games [25]. The highlight of this case is that every team in the MLB plays 81 games every single year [25]. This means that each sports team should travel to 40 games to compete at the opponent's home stadium [25]. At the same time, there is a large number of spectators who follow their favorite teams to games away from their home stadium [17-25]. Other examples include sporting events that take place every four years, such as the Federation International Football Association (FIFA) World Cup, the Olympic Games, the Euro Football Championship and the Rugby World Cup [23]. Approximately, 3 million spectators attend each of the aforementioned events and it has been estimated that they travel more than 2000 miles [9,23].

\section{Sports Facilities}

Sporting events also have large venues that that usually are built to accommodate 40,000 to 90,000 spectators [24]. For example, a sports facility that hosts the American college football games 
has an average capacity of 90,000 seats $[25,26]$. Sporting events would not reach such large numbers of spectators and media publicity if there were no sport facilities, venues and complexes that were state-of-art for the sports industry [26]. The innovative technology and aesthetic designs have been part of the progress of the sports industry when new sport facilities are built and they have a significant cost on the natural environment $[10,26]$. However, this is a controversial example, as the costly and innovative technologies used to build the stadiums primarily aim to reduce $\mathrm{CO}_{2}$ emissions [10-12].

Based on the above literature, the attitudes and behaviors of people who engage in the sports industry activities should change toward the protection of the natural environment and the control of climate change [19]. Essentially, stakeholders, consumers and associates of the sports industry that participate and host sporting events should promote environmentally-friendly practices in sports facilities during the everyday routine for the greener practice of the buildings [19-22].

\section{Transportation}

A recent study by Triantafyllidis et al. [3] reported that 90,000 spectators attend an American college football event. Spectators travel more than 80 miles and they primarily used an SOV and secondary they carpool [2-5]. The single drivers were estimated to generate $14.59 \mathrm{~kg}$ of $\mathrm{CO}_{2}$ emissions per person and spectators who shared a vehicle with other spectators generated $17.73 \mathrm{~kg}$ of $\mathrm{CO}_{2}$ emissions [3]. The quantity of $\mathrm{CO}_{2}$ emissions from spectators' transportation to a single college football game is approximately 1 million kilograms of $\mathrm{CO}_{2}$ [3]. In addition, there is evidence that environmental impacts derived from Canadian college varsity sports event transportation plays a critical role in the degradation of environmental quality [22]. Similarly, in European professional sports, spectators' transportation was the primary source of $\mathrm{CO}_{2}$ emissions emitted into the environment [3-5].

\section{Problem Indication}

Consequently, if there were a quantitative assessment that would capture the total amount of $\mathrm{CO}_{2}$ emissions produced by the entire process of one large-scale sporting event, it is expected that the quantity of $\mathrm{CO}_{2}$ emissions would be enormous. Essentially, there is an urgency for policy development with respect to the environmental initiatives of large-scale sporting events that are hosted weekly across the globe.

\section{Solutions}

No previous study has illustrated the negative impact of the sports industry on climate change. This study displays the sources of $\mathrm{CO}_{2}$ emissions and concludes that attention should be given to sport facility operations and spectator transportation in sports events. Therefore, innovative technologies should be integrated into sports facilities: proposals include renewable energy sources and electric car stations [27]. These practices are a preliminary approach toward controlling $\mathrm{CO}_{2}$ emissions from the facility and building construction and an innovation perspective. Accordingly, policies that target sporting events should be developed to control a large number of attendees and the place that sports organizations choose to host them. For instance, places that accommodate public transportation such as high-density urban areas should be first choice for facilitating sporting events and building stadiums [2,3]. Spectators' lack of knowledge with respect to their negative impact on the environment makes them use single-operation vehicles more often. In addition, spectators care mostly about their comfort and convenience when traveling [19-22]. Therefore, to achieve effective $\mathrm{CO}_{2}$ emissions management, sports organizations should consider how their practices and choice of a venue could reduce the amount of $\mathrm{CO}_{2}$ emissions that are derived from the transportation sports consumers.

Funding: This research did not receive any external funding.

Conflicts of Interest: The authors declare no conflict of interest. 


\section{References}

1. Mann, M.E.; Rahmstorf, S.; Kornhuber, K.; Steinman, B.A.; Miller, S.K.; Coumou, D. Influence of anthropogenic climate change on planetary wave resonance and extreme weather events. Sci. Rep. 2017, 7, 45242. [CrossRef] [PubMed]

2. Dosumu, A.; Colbeck, I.; Bragg, R. Greenhouse gas emissions as a result of spectators travelling to football in England. Sci. Rep. 2017, 7, 6986. [CrossRef] [PubMed]

3. Triantafyllidis, S.; Ries, R.J.; Kaplanidou, K.K. Carbon Dioxide Emissions of Spectators' Transportation in Collegiate Sporting Events: Comparing On-Campus and Off-Campus Stadium Locations. Sustainability 2018, 10, 241. [CrossRef]

4. United Nation Environmental Program (2018). Sport and the Environment. Available online: http:/ / www. unep.org/sport_env/ (accessed on 23 September 2018).

5. United States Environmental Protection Agency. Greenhouse Gas. (GHG) Emissions. Available online: https:/ / www.epa.gov/ghgemissions (accessed on 8 August 2018).

6. Chard, C.; Mallen, C. Examining the linkages between automobile use and carbon impacts of community-based ice hockey. Sport Manag. Rev. 2012, 15, 476-484. [CrossRef]

7. Schmidt, C.W. Putting the earth in play: Environmental awareness and sports. Environ. Health Perspect. 2006, 114, 286-295. [CrossRef] [PubMed]

8. Collins, A.; Cooper, C. Measuring and managing the environmental impact of festivals: The contribution of the Ecological Footprint. J. Sustain. Tour. 2017, 25, 148-162. [CrossRef]

9. International Olympic Committee. Manual on Sport and the Environment. Available online: http:// www.olympic.org/Documents/Commissions_PDFfiles/manuel_sport_environment_en.pdf (accessed on 12 September 2018).

10. Kellison, T.B.; Mondello, M.J. Organizational perception management in sport: The use of corporate pro-environmental behavior for desired facility referenda outcomes. Sport Manag. Rev. 2012, 15, 500-512. [CrossRef]

11. Casper, J.M.; Pfahl, M.E.; McCullough, B. Intercollegiate sport and the environment: Examining fan engagement based on athletics department sustainability efforts. J. Issues Intercoll. Athl. 2014, 7, 65-91.

12. Babiak, K.; Trendafilova, S. CSR and environmental responsibility: Motives and pressures to adopt green management practices. Corp. Soc. Responsib. Environ. Manag. 2011, 18, 11-24. [CrossRef]

13. Babiak, K.; Wolfe, R. Determinants of corporate social responsibility in professional sport: Internal and external factors. J. Sport Manag. 2009, 23, 717-742. [CrossRef]

14. McCullough, B.P. The Recycling Intentions of Sport Spectators: A Theory of Planned Behavior Approach. Ph.D. Thesis, Texas A \& M University, College Station, TX, USA, May 2011.

15. McCullough, B.P.; Kellison, T.B. Routledge Handbook of Sport and the Environment; Routledge Handbooks Online: New York, NY, USA, 2018; ISBN 9781138666153.

16. Schmied, M.; Hochfeld, C.; Stahl, H.; Roth, R.; Arbruster, F.; Turk, S.; Friedl, C. Green Champion in Sport and Environment: Guide to Environmentally-Sound Large Sporting Events; Federal Ministry for the Environment, Nature Conservation and Nuclear Safety and German Olympic Sports Confederation (DOSB), Division Development of Sports: Frankfurt, German, 2007.

17. Triantafyllidis, S.; Kaplanidou, K. Health and self- motivation as predictors of marathon runners' pro-environmental behaviors. In Proceedings of the North American Society for Sport Management Conference, Denver, CO, USA, 30 May-3 June 2017.

18. Triantafyllidis, S.; Kaplanidou, K. Olympus mountain marathon participants and voluntary carbon offsetting intentions. In Proceedings of the North American Society for Sport Management Conference, Halifax, NS, Canada, 5-9 June 2018.

19. Triantafyllidis, S. Sense of Place and Pro-Environmental Behavior in Beach Volleyball. Ph.D. Thesis, University of Florida, Gainesville, FL, USA, August 2018.

20. Chernushenko, D. Greening Our Games: Running Sports Events and Facilities That Won't Cost the Earth; Centurion Publishing \& Marketing: Ottawa, ON, Canada, 1994; ISBN 0969757158.

21. Collins, A.; Roberts, A.; Munday, M. The Environmental Impacts of Major Cycling Events: Reflections on the UK Stages of the Tour de France; Cardiff University: Cardiff, UK, 2012; Available online: http: / / orca.cf.ac.uk/ 53325/1/Tour-de-France.pdf (accessed on 2 May 2016). 
22. Dolf, M.; Teehan, P. Reducing the carbon footprint of spectator and team travel at the University of British Columbia's varsity sports events. Sport Manag. Rev. 2015, 18, 244-255. [CrossRef]

23. Federation International Football Association. Available online: https://www.fifa.com/ (accessed on 15 September 2018).

24. Major League Baseball. MLB Greening Program. Available online: http://web.mlbcommunity.org/index. jsp?content=programs\&program=team_greening_program (accessed on 1 September 2018).

25. Crossman, M. When the party's over. Sport. News 2008, 37, 232.

26. University Athletic Association. Available online: http://uaasports.info/landing/index (accessed on 12 September 2018).

27. Mihyeon, J.C.; Amekudzi, A. Addressing sustainability in transportation systems: Definitions, indicators, and metrics. J. Infrastruct. Syst. 2005, 11, 31-50. [CrossRef]

2018 by the author. Licensee MDPI, Basel, Switzerland. This article is an open access article distributed under the terms and conditions of the Creative Commons Attribution (CC BY) license (http:/ / creativecommons.org/licenses/by/4.0/). 